\title{
RESPONSE OF CAULIFLOWER TO NITROGEN FIXING BIOFERTILIZER AND GRADED LEVELS OF NITROGEN
}

Lila Nath Bashyal MSc (Ag) ${ }^{1}$

\begin{abstract}
A field experiment was carried out at Rampur, Chitwan, Nepal during September, 2007 to February, 2008 to assess the response of cauliflower (Brassica oleracea L. var. botrytis cv. Kathmandu Local) to biofertilizer containing free living nitrogen fixing bacteria Azospirillum and Azotobacter and different levels of nitrogen. The experiment was laid out in factorial Randomized Complete Block Design consisting of 10 treatments (nitrogen 0 , 30, 60, 90 and $120 \mathrm{~kg} \mathrm{ha}^{-1}$ alone and in combinations of $2 \mathrm{~kg}$ of the nitrogen fixing biofertilizer) arranged in $5 \times 2$ complete factorial with 3 replications. Application of nitrogen along with the biofertilizer significantly increased morphological, yield and quality characters as compared to application of nitrogen without biofertilizer. The maximum stem height, stem diameter, highest curd height, curd diameter, fresh curd weight and curd yield were recorded at $120 \mathrm{~kg}$ nitrogen and $2 \mathrm{~kg}$ biofertilizer ha ${ }^{-1}$. Cauliflower curd yield obtained at $120 \mathrm{~kg}$ nitrogen ha ${ }^{-1}$ did not significantly differ with the curd yield recorded at $60 \mathrm{~kg}$ nitrogen and $2 \mathrm{~kg}$ biofertilizer ha ${ }^{-1}$. The earliest days to curd initiation and maturity were recorded at $30 \mathrm{~kg}$ nitrogen and $2 \mathrm{~kg}$ biofertilizer $\mathrm{ha}^{-1}$. The highest vitamin $C$ content of curds and the most attractive curd color were recorded at 60 $\mathrm{kg}$ nitrogen and $2 \mathrm{~kg}$ biofertilizer $\mathrm{ha}^{-1}$, while the appearance and over all acceptability were recorded at $120 \mathrm{~kg}$ nitrogen and $2 \mathrm{~kg}$ biofertilizer ha ${ }^{-1}$. The finding demonstrated a saving of $60 \mathrm{~kg}$ nitrogen $\mathrm{ha}^{-1}$ without significantly affecting yield.
\end{abstract}

Key words: Azospirillum, azotobacter, biofertilizer, cauliflower, nitrogen

\section{INTRODUCTION}

Cauliflower (Brassica oleracea L. var. botrytis) is an important commercial vegetable grown in Nepal and is one of the highly preferred vegetables in Nepalese kitchen. Being a heavy feeder, cauliflower demands constant supply of large amount of nutrients and water for its luxuriant growth. A yield of $50 \mathrm{t} \mathrm{ha}^{-1}$ cauliflower removes approximately $200 \mathrm{~kg}$ nitrogen, 85 $\mathrm{kg}$ phosphorus and $270 \mathrm{~kg}$ potassium (Chaudhary, 1977). Its productivity depends on the use of balanced fertilizer and if not adequately fertilized, considerable yield losses are apparent (Chatterjee, 1993).

The global energy crisis has increased the cost of the chemical fertilizers and this trend is expected to continue. In spite of the unlimited reservoir of nitrogen in the air, manufacturing of $1 \mathrm{~kg}$ fertilizer $\mathrm{N}$ requires six times more energy than that needed to produce either $\mathrm{P}$ or $\mathrm{K}$ fertilizers. The energy requirement $\mathrm{Kg}^{-1}$ fertilizer is $11.2 \mathrm{KWh}$ for nitrogen, $1.1 \mathrm{KWh}$ for phosphorus and $1 \mathrm{KWh}$ fro potassium (Da Silva et at, 1978). The cost of chemical fertilizers will reach beyond the reach of marginal farmers in near future. The industrial nitrogen fixation not only depletes our finite reserves of fossil fuels, but also generates large quantities of principal greenhouse gas, nitrous oxide, which is 300 times more toxic than carbon dioxide. The indiscriminate use of chemical fertilizers increases soil acidity, impairs soil physical condition, reduces organic matter, creates micro nutrient deficiencies, increases plant susceptibility to pests and diseases, decreases soil lives, increases soil, water and air pollution via agricultural run - off and leaching (Joshi and Singh, 2004). A spoonful of soil contains more organisms than there are people on the

1 The Lutheran World Federation Nepal, Kath Email: pm_fhkep@Iwf.org.np, Inbashyal@hotmail.com 
earth, 1 billion bacteria, 10-20 million actinomycetes, 1 million fungi, 10,020 million protozoa, 100,000 algae and some worms and insects (Cosico, 1994). Chemical fertilizers destroy these soil lives.

Above every hectare of land, the air contains 78,000 t (Motsara et al., 1999) of nitrogen in gaseous form equivalent to about 170,000 t of urea fertilizer. The ability to utilize this free inert nitrogen gas is limited to certain prokaryotic organisms. Although biofertilizer is low cost input, compatible with chemical fertilizers and pesticides, safe to crop and users both, eco friendly and pose no danger to the environment; their acceptability have been rather low, chiefly because farmers are unaware of the appropriate integration of biofertilizer with nitrogen. Therefore, an experiment was carried out to assess the response of cauliflower to nitrogen fixing biofertilizer and graded levels of nitrogen under Chitwan condition.

\section{MATERIALS AND METHODS}

The experiment was conducted at Horticulture Farm of the Institute of Agriculture and Animal Science, Rampur, Chitwan during September 2007 to February 2008. The experiment was laid out in factorial Randomized Complete Block Design consisting of 10 treatments (nitrogen $0,30,60,90$ and $120 \mathrm{~kg} \mathrm{ha}^{-1}$ alone and in combinations of $2 \mathrm{~kg}$ of the nitrogen fixing biofertilizer) arranged in $5 \times 2$ complete factorial with 3 replications.

Well decomposed FYM was mixed equally in each plot at $20 \mathrm{t} \mathrm{ha}^{-1}$ at final land preparation. Half dose of nitrogen as specified in the treatments was applied through urea $(46 \% \mathrm{~N})$ at final land preparation as basal dose. Remaining amount of nitrogen was split into two equal parts and top dressed at 30 and 60 days after transplantation. Full amount of recommended dose of phosphorus $\left(60 \mathrm{~kg} \mathrm{ha}^{-1}\right)$, potassium $\left(40 \mathrm{~kg} \mathrm{ha}^{-1}\right)$ and boran $\left(15 \mathrm{~kg} \mathrm{ha}^{-1}\right)$ was applied as basal dose through Single Super Phosphate $\left(16 \% \mathrm{P}_{2} \mathrm{O}_{5}\right)$ and Murate of Potash $\left(60 \% \mathrm{~K}_{2} \mathrm{O}\right)$ and Borax $\left(\mathrm{Na}_{2} \mathrm{~B}_{4} \mathrm{O}_{7} .10 \mathrm{H}_{2} \mathrm{O}\right)$ respectively at final land preparation stage. Nitrofix biofertilizer, containing Azospirillum and Azotobacter bacteria $(1 \% \mathrm{~W} / \mathrm{W})$ having more than $1.5 \times 107$ colony forming units per gram, was applied at the rate of $2 \mathrm{~kg} \mathrm{ha}^{-1}$. Biofertilizer mixed with $50 \mathrm{~kg}$ of well decomposed FYM and left overnight. This mixture was applied in the soil in root zone of plants and thoroughly mixed with soil at the time of transplanting. Kathmandu Local, a popular open pollinated mid season variety of cauliflower in Nepal was used as a test crop.

Morphological characters of central 5 tagged plants viz. stem height, stem diameter were recorded at 20, 40, 60 days after transplantation and at harvest stage. Yield attributes viz. curd height, curd diameter, fresh weight of curds, curd yield, days to curd initiation and maturity were recorded. Quality parameters viz. vitamin C content of fresh curds, physiological loss in weight and spoilage loss of curd were tested. Sensory evaluation was made to judge the color, compactness, hollowness, appearance and overall acceptability of the fresh curd at harvest stage by a panel of 10 persons by using hedonic scale of 1 to 9 , where 1 indicates the poor and 9 the excellent performance.

The agro meteorological data for the crop growing period were obtained from National Maize Research Program, Rampur, Chitwan. The mean maximum temperature, minimum temperature, relative humidity and rainfall were 27.05 OC, 14.17 OC, $95.06 \%$ and $3.4 \mathrm{~mm}$ per week respectively for the crop growing season. The maximum temperature ranged from 19.25 OC (4th week of January) to 35.43 OC (1st week of October). Similarly, the minimum temperature ranged between 6.75 OC (3rd week of December) to 30.44 OC (3rd week of October) for the crop season.

Composite soil samples from each block of the experimental field were taken from the upper $30 \mathrm{~cm}$ depth before the field experiment. There were three composite soil samples for chemical analysis. Total nitrogen was determined by Macro-Kjeldahl method (Jackson, 
1967), available phosphorus by Olsen's bicarbonate method (Olsen, 1965), and available potassium by Natural normal ammonium acetate method (Black, 1965). Organic matter was determined by Walkely and Black method (1934), pH by Beckman Glass Electrode pH meter (Wright, 1939) and soil texture by hydrometer method in Central Soil Science Laboratory of NARC, Khumaltar. The report of the soil test is presented in Annex 1.

The mean values of triplicate data of different parameters were analyzed by MSTATC (1990). Data were subjected to analysis of variance (ANOVA) to evaluate the significance of treatment effect. Means were separated using Duncan's Multiple Range Test (DMRT) at 5\% level of significance.

\section{RESULTS AND DISCUSSIONS}

\section{CURD YIELD AND YIELD ATTRIBUTES}

\section{Curd yield}

Curd yield, the economic product of cauliflower, is due to the combined effect of growth, development and yield attributes. The main effects of nitrogen, biofertilizer and their interactions were highly significant $(p<0.01)$ on curd yield (Table1). The main effect of nitrogen on curd yield was the highest $\left(15.01 \mathrm{t} \mathrm{ha}^{-1}\right)$ at $120 \mathrm{~kg} \mathrm{~N} \mathrm{ha}^{-1}$ which was significantly higher than those recorded at $90,60,30 \mathrm{~kg} \mathrm{~N}^{-1}$ and at control. The lowest curd yield $(4.5$ $\mathrm{t} \mathrm{ha}^{-1}$ ) was recorded at control. Curd yield was significantly increased as the level of nitrogen increased from 0 to $120 \mathrm{~kg} \mathrm{ha}^{-1}$. Application of biofertilizer at $2 \mathrm{~kg} \mathrm{ha}^{-1}$ had shown significantly higher curd yield $\left(11.51 \mathrm{t} \mathrm{ha}^{-1}\right)$ than in control. The interaction effects of nitrogen and biofertilizer was highly significant $(\mathrm{p}<0.01)$ on curd yield (Table 1$)$.

Table1: Interaction effects of nitrogen and biofertilizer on curd yield ,

\begin{tabular}{|c|c|c|c|c|}
\hline Treatments $\left(\mathrm{kg} \mathrm{ha}^{-1}\right)$ & Curd height $(\mathrm{cm})$ & Curd diameter $(\mathrm{cm})$ & Curd weight (g plant ${ }^{-1}$ ) & Curd yield $\left(\mathrm{t} \mathrm{ha}^{-1}\right)$ \\
\hline $\mathrm{NO} \times \mathrm{BO}$ & $5.61 \mathrm{f}$ & $8.34 \mathrm{f}$ & $125.40 \mathrm{~g}$ & $3.48 \mathrm{~g}$ \\
\hline $\mathrm{NO} \times \mathrm{B} 2$ & 6.87 ef & $11.82 \mathrm{de}$ & $205.68 \mathrm{f}$ & $5.72 \mathrm{f}$ \\
\hline $\mathrm{N} 30 \times \mathrm{B} 0$ & $7.85 \mathrm{e}$ & $11.44 \mathrm{e}$ & $150.48 \mathrm{~g}$ & $4.18 \mathrm{~g}$ \\
\hline $\mathrm{N} 30 \times \mathrm{B} 2$ & $10.23 \mathrm{~d}$ & $14.49 \mathrm{~cd}$ & $259.56 \mathrm{e}$ & $7.21 \mathrm{e}$ \\
\hline $\mathrm{N} 60 \times \mathrm{B} 0$ & $10.09 \mathrm{~d}$ & $13.32 \mathrm{cde}$ & $216.00 \mathrm{f}$ & $6.0 \mathrm{f}$ \\
\hline $\mathrm{N} 60 \times \mathrm{B} 2$ & $13.14 \mathrm{c}$ & $17.52 \mathrm{~b}$ & $426.12 \mathrm{c}$ & $11.84 \mathrm{c}$ \\
\hline $\mathrm{N} 90 \times \mathrm{B} 0$ & $11.45 \mathrm{~cd}$ & $14.86 \mathrm{bc}$ & $329.31 \mathrm{~d}$ & $9.15 \mathrm{~d}$ \\
\hline $\mathrm{N} 90 \times \mathrm{B} 2$ & $15.76 \mathrm{~b}$ & $22.77 \mathrm{a}$ & $524.40 \mathrm{~b}$ & $14.57 \mathrm{~b}$ \\
\hline $\mathrm{N} 120 \times \mathrm{B} 0$ & $13.03 \mathrm{c}$ & $15.75 \mathrm{bc}$ & $421.81 \mathrm{c}$ & $11.72 \mathrm{c}$ \\
\hline $\mathrm{N} 120 \times \mathrm{B} 2$ & $18.72 \mathrm{a}$ & $22.62 \mathrm{a}$ & $658.68 \mathrm{a}$ & $18.3 \mathrm{a}$ \\
\hline$F$ test of $A \times B$ & * & * & $* *$ & $* *$ \\
\hline LSD 0.05 & 1.74 & 2.56 & 35.37 & 0.98 \\
\hline $\mathrm{SEm} \pm$ & 0.58 & 0.86 & 11.87 & 0.33 \\
\hline CV (\%) & 8.97 & 9.76 & 6.2 & 6.2 \\
\hline
\end{tabular}

Means followed by the same letter (s) in column are not significantly different at $5 \%$ level as determined by DMRT.

Curd yield increased as the level of nitrogen increased from 0 to $120 \mathrm{~kg} \mathrm{ha}^{-1}$ with biofertilizer. The highest curd yield $\left(18.3 \mathrm{t} \mathrm{ha}^{-1}\right)$ was recorded at $120 \mathrm{~kg} \mathrm{~N} \mathrm{ha}^{-1}$ with $2 \mathrm{~kg}$ biofertilizer ha ${ }^{-1}$ followed by those recorded at $90 \mathrm{~kg} \mathrm{~N} \mathrm{ha}^{-1}$ with $2 \mathrm{~kg}$ biofertilizer ha ${ }^{-1}$. Curd 
yield recorded at $120 \mathrm{~kg} \mathrm{~N} \mathrm{ha}^{-1}$ was statistically at par to those recorded at $60 \mathrm{~kg} \mathrm{~N} \mathrm{ha}^{-1}$ with $2 \mathrm{~kg}$ biofertilizer ha-1. Curd yield recorded at $60 \mathrm{~kg} \mathrm{~N} \mathrm{ha}^{-1}$ was at par to those recorded $2 \mathrm{~kg}$ biofertilizer ha ${ }^{-1}$.

Curd yield, height, diameter and fresh weight increased with increase in $\mathrm{N}$ dose and biofertilizer application from 0 to $120 \mathrm{~kg} \mathrm{~N}$ and biofertilizer Biofertilizer enhances phytohormone production, nitrate reduction, nitrogen fixation, phosphate solubilization, specific activities of enzymes involved in the tricarboxylic acid cycle and the glycolysis pathway might be the reason behind yield increase. Hormone induced modification in root morphology leads to enhanced uptake of mineral nutrients like $\mathrm{NO}_{3}{ }^{-}, \mathrm{NH}_{4}{ }^{+}, \mathrm{H}_{2} \mathrm{PO}_{4}{ }^{+}, \mathrm{K}^{+}, \mathrm{Rb}^{+}$ and $\mathrm{Fe}^{2+}$ might help increasing yield. Azospirillum can fix as much as $15 \mathrm{mg} \mathrm{N} \mathrm{g}^{-1}$ of glucose utilized. Azotobacter is able to fix $6.0-13.4 \mathrm{mg}$ nitrogen per gram of sucrose consumed. Azotobacter solubilized the tricalcium phosphate with the same intensity as did the standard organism, Bacillus spp. Azotobacter is able to inhibit the growth of phytopathogenic fungi species such as Alternaria, Venturia, Sclerotinia, Rhizoctonia, and Pythium and thus, enable the plants to grow well without disease, which may help in increasing cauliflower yield. These findings are come in conformity with the findings of Budhathoki (2006), Bhhattarai et al., (2005), Joshi and Singh (2004), and Bhattacharya et al., (2000) who have reported increased in cauliflower yield using biofertilizer with different nitrogen levels.

\section{Curd height and diameter}

The main effect of nitrogen and biofertilizer on curd height and curd diameter is presented in Table 1. The main effect of nitrogen and biofertilizer was highly significant $(p<0.01)$ on increasing cauliflower curd height and diameter. The maximum curd height $(15.87 \mathrm{~cm})$ and curd diameter $(19.18 \mathrm{~cm})$ was recorded at $120 \mathrm{~kg} \mathrm{~N} \mathrm{ha}^{-1}$. Similarly, the maximum curd height $(12.94 \mathrm{~cm})$ and curd diameter $(17.84 \mathrm{~cm})$ was recorded at $2 \mathrm{~kg}$ biofertilizer ha-1 which was significantly higher than those recorded at control.

There was significant $(p<0.05)$ interaction effects of nitrogen and biofertilizer on increasing curd height and curd diameter (Fig.1). Curd height and diameter significantly increased as the level of nitrogen increased from 0 to $120 \mathrm{~kg} \mathrm{ha}^{-1}$ with $2 \mathrm{~kg}$ biofertilizer ha ${ }^{-1}$. The maximum curd height $(18.72 \mathrm{~cm})$ and curd diameter $(22.62 \mathrm{~cm})$ recorded at $120 \mathrm{~kg} \mathrm{~N} \mathrm{ha}^{-1}$ with $2 \mathrm{~kg}$ biofertilizer $\mathrm{ha}^{-1}$ followed by those recorded at $90 \mathrm{~kg} \mathrm{~N} \mathrm{ha}^{-1}$ and $2 \mathrm{~kg}$ biofertilizer ha-. Curd height and curd diameter recorded at $120 \mathrm{~kg} \mathrm{~N} \mathrm{ha}^{-1}$ was statistically at par to those recorded at $60 \mathrm{~kg} \mathrm{~N} \mathrm{ha}^{-1}$ and $2 \mathrm{~kg}$ biofertilizer ha ${ }^{-1}$.

Curd height and curd diameter increased with biofertilizer is not just related to the capacity to fix atmospheric nitrogen but also, due to the production of plant growth promoting substances. These phytohormones promote root growth of the plants, consequently increasing nutrients and water absorption areas. Biofertilizer saved soil microorganisms; increased nutrient mobilization from non available form to available form, improved physic-chemical properties of soil inhibited the growth of pathogenic organisms and made plant healthy, resulting in increasing yield attributes.

\section{Fresh curd weight}

Main effects of nitrogen, biofertilizer and their interactions on fresh curd weight were highly significant (Table 1). Fresh curd weight increased as the level of nitrogen increased along with biofertilizer. Significantly highest curd weight $\left(658.68 \mathrm{~g} \mathrm{plant}^{-1}\right)$ was recorded at $120 \mathrm{~kg} \mathrm{~N} \mathrm{ha}^{-1}$ and $2 \mathrm{~kg}$ biofertilizer ha- ${ }^{-1}$ followed by those recorded at $90 \mathrm{~kg} \mathrm{~N} \mathrm{ha}^{-1}$ and $2 \mathrm{~kg}$ biofertilizer ha ${ }^{-1}$. Similarly, fresh curd weight recorded at $60 \mathrm{~kg} \mathrm{~N} \mathrm{ha}^{-1}$ was statistically at par to those recorded $2 \mathrm{~kg}$ biofertilizer ha ${ }^{-1}$.

Bioinoculation of biofertilizer increased the activities of rhizosphere bacteria involved in ammonification, anaerobic nitrogen fixation, nitrification and cellulose decomposition. 
Azotobacter also affected plant growth indirectly by changing the microflora of rhizosphere and by maintaining the balance between harmful and beneficial organisms in the soil. The abilities of Azospirillum and Azotobacter have been postulated to be partially due to production of phytohormones, including gibberellins, cytokines like substances and auxins from tryptophan, ethylene and vitamins and partially due to nitrogen fixation, phosphate solubilization (Fulchieri et al., 1993). The increase in curd weight may be due to increased supply of nitrogen, which may accelerate synthesis of chlorophyll, amino acids, enzymes and carbohydrate use.

\section{Days to curd initiation and maturity}

Curd initiation is the transformation of vegetative phase to reproductive phase. The main effect of nitrogen and biofertilizer had highly significant $(p<0.01)$ effect, while their interaction was significant $(\mathrm{p}<0.05)$ on reducing days to curd initiation and maturity days (Fig.1). The shortest days to curd initiation (55.57) was recorded at $30 \mathrm{~kg} \mathrm{~N} \mathrm{ha}^{-1}$ and $2 \mathrm{~kg}$ biofertilizer ha ${ }^{-1}$. The longest days to curd initiation (73.97) was recorded at $120 \mathrm{~kg} \mathrm{~N} \mathrm{ha}{ }^{-1}$. Similarly, the shortest days to curd maturity (73.77) was recorded at $30 \mathrm{~kg} \mathrm{~N}^{-1}$ and $2 \mathrm{~kg}$ biofertilizer ha ${ }^{-1}$. The most delayed (92.17 days) curd initiation was observed at $120 \mathrm{~kg} \mathrm{~N}$ $\mathrm{ha}^{-1}$. The days to curd initiation increased with increased levels of nitrogen. Higher amount of nitrogen permits luxurious growth of the plant and delays maturity. Curd initiation and maturity delayed with increase in $\mathrm{N}$ content and Biofertilizer application due to increase in vegetative period.

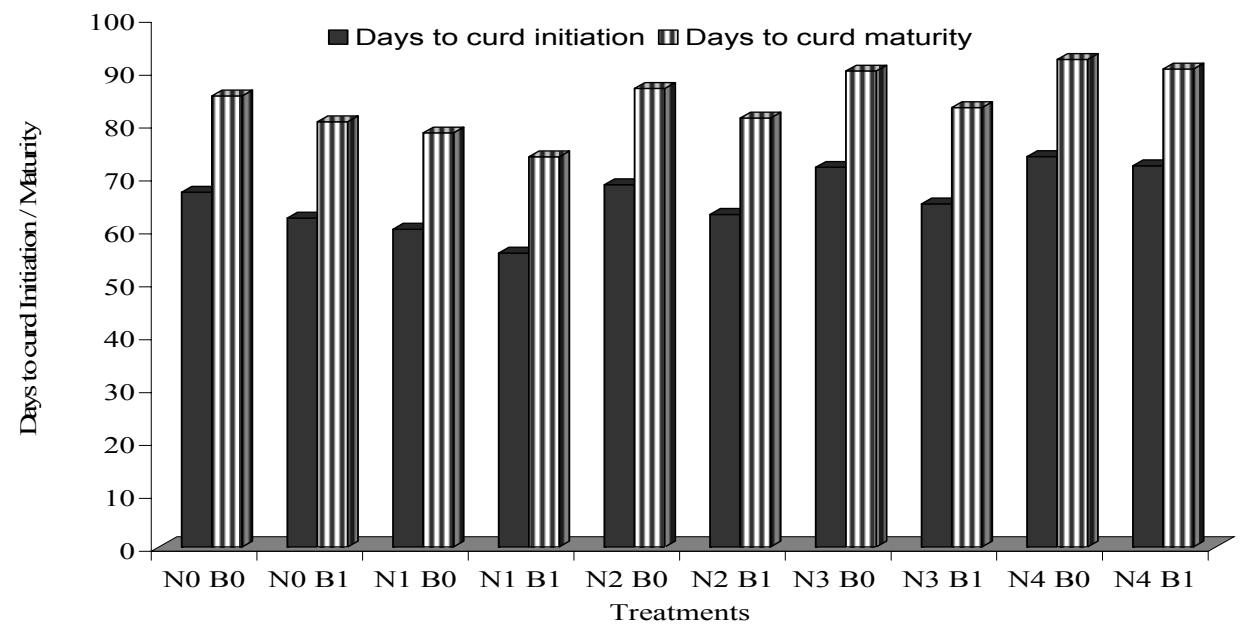

Fig 1: Interaction effects of nitrogen and biofertilizer and on days to curd imitation and maturity of cauliflower at Rampur during 2007 - 2008

\section{CURD QUALITY PARAMETERS}

\section{Vitamin C content}

The main effect of nitrogen and biofertilizer on vitamin $C$ content of fresh cauliflower curds was highly significant $(p<0.01)$ and their interactions was significant $(p<0.05)$ (Fig. 2$)$. Vitamin $\mathrm{C}$ content decreased beyond $60 \mathrm{~kg} \mathrm{~N} \mathrm{ha}^{-1}$ but biofertilizer increased Vit $\mathrm{C}$ content. Ascorbic acid content increased as the level of nitrogen increased from 0 to $60 \mathrm{~kg} \mathrm{~N} \mathrm{ha}{ }^{-1}$ and further increase in nitrogen decreased vitamin C content. Significantly higher vitamin $\mathrm{C}$ content was recorded at $2 \mathrm{~kg}$ biofertilizer ha ${ }^{-1}$. The maximum vitamin $\mathrm{C}$ content of curds $(11.18 \mathrm{mg} / 100 \mathrm{~g})$ was recorded at $60 \mathrm{~kg} \mathrm{~N} \mathrm{ha}^{-1}$ and $2 \mathrm{~kg}$ biofertilizer ha ${ }^{-1}$ followed by those recorded at $2 \mathrm{~kg}$ biofertilizer $\mathrm{ha}^{-1}$, but these two treatments were at par. Ascorbic acid 
content recorded at $2 \mathrm{~kg}$ biofertilizer ha ${ }^{-1}, 60 \mathrm{~kg} \mathrm{~N}^{-1}$ and $90 \mathrm{~kg} \mathrm{~N}^{-1}$ with $2 \mathrm{~kg}$ biofertilizer $\mathrm{ha}^{-1}$ were similar.

Biofertilizer inoculation in bitter gourd at the rate of $1 \mathrm{~kg} \mathrm{ha}^{-1}$ along with $70 \mathrm{~kg} \mathrm{~N} \mathrm{ha}{ }^{-1}$ significantly improved vitamin C and protein content of fruits Subbiah (1994). Nutrient content in chili, onion, okra, cabbage, brinjal, tomato and cauliflower was increased, when Azospirillum is applied at the rate of $2 \mathrm{~kg} \mathrm{ha}^{-1}$ (Subbiah 1994). Author reported that integrated approach of Azotobacter inoculation to tomato seedlings with full dose of NPK and FYM increased ascorbic acid content of fruits. Authors found that the highest fertilizer rate increased vitamin $\mathrm{C}$ content and crude protein content of cauliflower curds. Organic crops contained significantly more vitamin C, iron, magnesium, phosphorus, substantially significant mineral with lower amounts of some heavy metals and significantly less nitrates than conventional crops

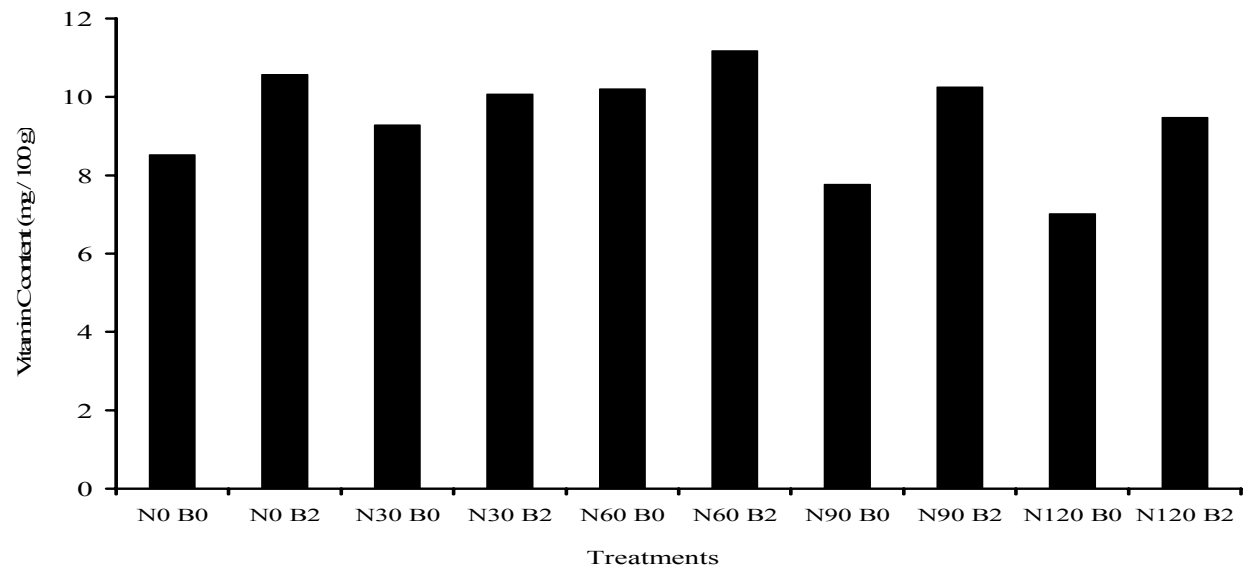

Fig.2: Interaction effects of nitrogen and biofertilizer on vitamin C content of fresh cauliflower curds of at Rampur during $2007-2008$

\section{Curd color}

There was highly significant $(p<0.01)$ interaction effects of nitrogen and biofertilizer on curd color (Table 2). The most appreciable color (8.87) was observed at $60 \mathrm{~kg} \mathrm{~N} \mathrm{ha}^{-1}$ and 2 $\mathrm{kg}$ biofertilizer ha ${ }^{-1}$ followed by those recorded at $120 \mathrm{~kg} \mathrm{~N} \mathrm{ha}^{-1}$ and $2 \mathrm{~kg}$ biofertilizer ha ${ }^{-1}$, but the results recorded at $60 \mathrm{~kg} \mathrm{~N} \mathrm{ha}^{-1}$ and $2 \mathrm{~kg}$ biofertilizer ha ${ }^{-1}, 120 \mathrm{~kg} \mathrm{~N} \mathrm{ha}^{-1}$ and $2 \mathrm{~kg}$ biofertilizer ha ${ }^{-1}, 90 \mathrm{~kg} \mathrm{~N} \mathrm{ha}^{-1}$ and $2 \mathrm{~kg}$ biofertilizer ha ${ }^{-1}$ and only $120 \mathrm{~kg} \mathrm{~N}^{-1}$ were statistically at par. Curd color increased with increase in $\mathrm{N}$ application and bifoertilizer also had positive impact. The poorest color (3.65) was observed at control. When nitrogen is deficit in plants it inhibits the synthesis of 6- phosphogluconate and glucose - 6 phosphate dehydrogenase and enhances the synthesis and builds up of phenolic compounds which gives rise browning of curds (Gupta and Samnotra, 2004).

\section{Curd compactness}

There was highly significant $(p<0.01)$ interactions between nitrogen and biofertilizer on curd compactness (Table 2 ). The best score of curd compactness (8.82) was observed at 90 $\mathrm{kg} \mathrm{N} \mathrm{ha}^{-1}$ and $2 \mathrm{~kg}$ biofertilizer ha ${ }^{-1}$. The curd compactness scores obtained at $60 \mathrm{~kg} \mathrm{~N} \mathrm{ha}^{-1}$ and $2 \mathrm{~kg}$ biofertilizer ha ${ }^{-1}, 90 \mathrm{~kg} \mathrm{~N}^{-1}$ and $2 \mathrm{~kg}$ biofertilizer ha ${ }^{-1}, 120 \mathrm{~kg} \mathrm{~N} \mathrm{ha}^{-1}$ and $2 \mathrm{~kg}$ biofertilizer ha- ${ }^{-1}, 90 \mathrm{~kg} \mathrm{~N}^{-1}$ and $120 \mathrm{~kg} \mathrm{~N} \mathrm{ha}^{-1}$ were similar. Significantly the poorest curd compactness was recorded at control. The curd compactness scores obtained at $60 \mathrm{~kg} \mathrm{~N} \mathrm{ha}^{-1}$ and $2 \mathrm{~kg}$ biofertilizer ha ${ }^{-1}, 90 \mathrm{~kg} \mathrm{~N}^{-1}$ and $2 \mathrm{~kg}^{-}$biofertilizer ha ${ }^{-1}, 120 \mathrm{~kg} \mathrm{~N} \mathrm{ha}^{-1}$ and $2 \mathrm{~kg}$ biofertilizer ha-1, $90 \mathrm{~kg} \mathrm{~N} \mathrm{ha}^{-1}$ and $120 \mathrm{~kg} \mathrm{~N} \mathrm{ha}^{-1}$ were similar. The increment may be due to 
more nutrient uptake ( $\mathrm{N}$ and perhaps $\mathrm{P}$ and other elements too) or due to production of plant growh promoting substance by biofertilizers The greater compactness of curd, caused by the inoculation of bacteria of the genera Azospirillum and Azotobacter is due to a larger nitrogen offer for the plant.

\section{Curd compactness}

Compactness of curd increases its weight, increases its marketing values. Main effects of nitrogen and biofertilizer was highly significant $(p<0.01)$ on increasing curd compactness but their interaction was non significant.

Table 2: Interaction effects of nitrogen and biofertilizer on curd quality of cauliflower

\begin{tabular}{|c|c|c|c|c|}
\hline \multirow{2}{*}{$\begin{array}{l}\text { Treatment } \\
\left(\mathrm{kg} \mathrm{ha}^{-1}\right)\end{array}$} & \multicolumn{4}{|c|}{ Curd Quality ( 9 is the highest and 1 is the lowest on $1-9$ hedonic scale) } \\
\hline & Color (1-9) & Compactness (1-9) & Appearance (1-9) & Overall acceptability (1-9) \\
\hline $\mathrm{NO} \times \mathrm{BO}$ & $3.65 \mathrm{~d}$ & $3.72 \mathrm{~d}$ & $1.21 \mathrm{~g}$ & $1.21 \mathrm{~g}$ \\
\hline NO $\times$ B2 & $6.09 c$ & $5.64 \mathrm{c}$ & $2.38 \mathrm{f}$ & $2.38 \mathrm{f}$ \\
\hline $\mathrm{N} 30 \times \mathrm{BO}$ & $5.56 \mathrm{c}$ & $5.71 \mathrm{c}$ & $2.37 \mathrm{f}$ & $2.35 \mathrm{f}$ \\
\hline $\mathrm{N} 30 \times \mathrm{B} 2$ & $7.54 \mathrm{~b}$ & $7.33 \mathrm{~b}$ & $3.73 \mathrm{e}$ & $3.71 \mathrm{e}$ \\
\hline $\mathrm{N} 60 \times \mathrm{B} 0$ & $8.2 \mathrm{ab}$ & $7.54 \mathrm{~b}$ & $3.49 \mathrm{e}$ & $3.47 \mathrm{e}$ \\
\hline $\mathrm{N} 60 \times \mathrm{B} 2$ & $8.87 \mathrm{a}$ & $8.71 \mathrm{a}$ & $4.95 \mathrm{~d}$ & $4.93 \mathrm{~d}$ \\
\hline $\mathrm{N} 90 \times \mathrm{B} 0$ & $8.43 \mathrm{a}$ & $8.78 \mathrm{a}$ & $4.87 \mathrm{~d}$ & $4.86 \mathrm{~d}$ \\
\hline $\mathrm{N} 90 \times \mathrm{B} 2$ & $8.68 \mathrm{a}$ & $8.82 \mathrm{a}$ & $6.73 \mathrm{~b}$ & $6.71 \mathrm{~b}$ \\
\hline $\mathrm{N} 120 \times \mathrm{B} 0$ & $8.45 \mathrm{a}$ & $8.48 \mathrm{a}$ & $6.18 \mathrm{c}$ & $6.17 \mathrm{c}$ \\
\hline $\mathrm{N} 120 \times \mathrm{B} 2$ & $8.83 \mathrm{a}$ & $8.63 \mathrm{a}$ & $8.87 \mathrm{a}$ & $8.75 \mathrm{a}$ \\
\hline$F$ test $A \times B$ & $* *$ & $* *$ & $* *$ & $* *$ \\
\hline LSD 0.05 & 0.84 & 0.75 & 0.37 & 0.37 \\
\hline $\mathrm{SEm} \pm$ & 0.28 & 0.25 & 0.13 & 0.13 \\
\hline CV (\%) & 6.56 & 5.95 & 6.85 & 7.82 \\
\hline
\end{tabular}

Means followed by the same letter (s) in column and row are not significantly different at $5 \%$ level as determined by DMRT.

\section{Appearance and over all acceptability}

The main effects of nitrogen and biofertilizer and their interaction was highly significant $(p<0.01)$ effects on the appearance and overall consumers' acceptability of cauliflower curds at harvest time (Table 2). The curd appearance and consumers' acceptability increased as the level of nitrogen increased from 0 to $120 \mathrm{~kg} \mathrm{ha}^{-1}$ and $2 \mathrm{~kg}$ biofertilizer ha- ${ }^{-1}$. The best attractive appearance (8.87) and the highest consumers' acceptability (8.75) was recorded at $120 \mathrm{~kg} \mathrm{~N} \mathrm{ha}^{-1}$ and $2 \mathrm{~kg}$ biofertilizer ha ${ }^{-1}$ followed by those recorded at $90 \mathrm{~kg} \mathrm{~N}$ $\mathrm{ha}^{-1}$ along with $2 \mathrm{~kg}$ biofertilizer $\mathrm{ha}^{-1}$.

\section{PHYSIOLOGICAL LOSS IN WEIGHT (PLW) AND SPOILAGE LOSS}

Application of nitrogen and biofertilizer had shown highly significant $(p<0.01)$ effects, but their interaction was non significant on increasing physiological loss in weight and spoilage loss of cauliflower curds stored with and without jacket leaves in ordinary room condition ( $20 \pm 3$ OC Temperature and $60 \pm 5 \%$ Relative Humidity) for 7 days. PLW increased as the nitrogen level increased from 0 to $120 \mathrm{~kg} \mathrm{ha}^{-1}$ and decreased with increased biofertilizer levels from 0 to $2 \mathrm{~kg} \mathrm{ha}^{-1}$. PLW of curds after 7 days of storage along with and without 
jacket leaves was recorded highest at $120 \mathrm{~kg} \mathrm{~N} \mathrm{ha}^{-1}$, followed by $90 \mathrm{~kg} \mathrm{~N} \mathrm{ha}^{-1}, 60 \mathrm{~kg} \mathrm{~N} \mathrm{ha}^{-1}$ and $30 \mathrm{~kg} \mathrm{~N} \mathrm{ha}^{-1}$. The maximum spoilage loss after 7 days of storage along with and without jacket leaves was recorded at $120 \mathrm{~kg} \mathrm{~N} \mathrm{ha}^{-1}$, followed by $90 \mathrm{~kg} \mathrm{~N} \mathrm{ha}^{-1}, 60 \mathrm{~kg} \mathrm{~N} \mathrm{ha}^{-1}$ and $30 \mathrm{~kg}$ $\mathrm{N}$ ha ${ }^{-1}$. The lowest spoilage loss was recorded at control.

\section{MORPHOLOGICAL CHARACTERS}

\section{Stem height and diameter}

The main effect of nitrogen and biofertilizer and their interactions on stem height and stem diameter of cauliflower was highly significant $(p<0.01)$ at $20,30,60$ days after transplantation and at harvest (Table 3). The direct plant growth promoting abilities of Azospirillum and Azotobacter have been postulated to be partially due to production of phytohormones, including GAs, cytokinins like substances, auxins, ethylene and vitamins and partially due to nitrogen fixation and phosphate solubilization.

Table 3: Interaction effects of nitrogen and biofertilizer on stem height and stem diameter of cauliflower at various crop growth stages during $2007-2008$

\begin{tabular}{lllllll}
\hline \multirow{2}{*}{$\begin{array}{l}\text { Treatments } \\
\left(\mathrm{kg} \mathrm{ha}^{-1}\right)\end{array}$} & \multicolumn{5}{l}{ Stem height $(\mathrm{cm})$} & \multicolumn{5}{l}{ Stem diameter $(\mathrm{cm})$} \\
\cline { 2 - 7 } $\mathrm{N} 0 \times \mathrm{B} 0$ & $20 \mathrm{DAT}$ & $40 \mathrm{DAT}$ & $60 \mathrm{DAT}$ & $20 \mathrm{DAT}$ & $40 \mathrm{DAT}$ & $60 \mathrm{DAT}$ \\
$\mathrm{N} 0 \times \mathrm{B} 2$ & $7.53 \mathrm{~g}$ & $12.73 \mathrm{f}$ & $17.17 \mathrm{f}$ & $0.31 \mathrm{~h}$ & $1.23 \mathrm{f}$ & $1.81 \mathrm{f}$ \\
$\mathrm{N} 30 \times \mathrm{B} 0$ & $7.17 \mathrm{fg}$ & $15.03 \mathrm{f}$ & $20.3 \mathrm{e}$ & $0.43 \mathrm{~g}$ & $1.35 \mathrm{e}$ & $1.93 \mathrm{e}$ \\
$\mathrm{N} 30 \times \mathrm{B} 2$ & $8.67 \mathrm{~cd}$ & $19.83 \mathrm{f}$ & $20.73 \mathrm{e}$ & $0.43 \mathrm{~g}$ & $1.35 \mathrm{e}$ & $1.93 \mathrm{e}$ \\
$\mathrm{N} 60 \times \mathrm{B} 0$ & $7.66 \mathrm{ef}$ & $18.83 \mathrm{e}$ & $24.9 \mathrm{~d}$ & $0.52 \mathrm{f}$ & $1.44 \mathrm{~d}$ & $2.02 \mathrm{~d}$ \\
$\mathrm{~N} 60 \times \mathrm{B} 2$ & $9.60 \mathrm{c}$ & $24.57 \mathrm{c}$ & $31.8 \mathrm{c}$ & $0.71 \mathrm{~cd}$ & $1.63 \mathrm{c}$ & $2.21 \mathrm{c}$ \\
$\mathrm{N} 90 \times \mathrm{B} 0$ & $8.26 \mathrm{de}$ & $21.77 \mathrm{~d}$ & $27.87 \mathrm{~d}$ & $0.57 \mathrm{e}$ & $1.49 \mathrm{~d}$ & $2.07 \mathrm{~d}$ \\
$\mathrm{~N} 90 \times \mathrm{B} 2$ & $11.04 \mathrm{~b}$ & $28.7 \mathrm{~b}$ & $35.5 \mathrm{~b}$ & $0.79 \mathrm{~b}$ & $1.72 \mathrm{ab}$ & $2.29 \mathrm{ab}$ \\
$\mathrm{N} 120 \times \mathrm{B} 0$ & $9.17 \mathrm{~cd}$ & $24.83 \mathrm{c}$ & $31.67 \mathrm{c}$ & $0.66 \mathrm{~d}$ & $1.58 \mathrm{c}$ & $2.16 \mathrm{c}$ \\
$\mathrm{N} 120 \times \mathrm{B} 2$ & $13.07 \mathrm{a}$ & $34.8 \mathrm{a}$ & $42.67 \mathrm{a}$ & $0.85 \mathrm{a}$ & $1.77 \mathrm{a}$ & $2.35 \mathrm{a}$ \\
\hline $\mathrm{A} \times \mathrm{B}$ & $* *$ & $* *$ & $*$ & $* *$ & $*$ & $*$ \\
LSD 0.05 & 0.93 & 2.34 & 3.01 & 0.05 & 0.07 & 0.07 \\
$\mathrm{SEm} \pm$ & 0.32 & 0.79 & 1.01 & 0.02 & 0.03 & 0.03 \\
$\mathrm{CV}(\%)$ & 6.1 & 6.35 & 6.3 & 5.99 & 5.06 & 4.21 \\
\hline
\end{tabular}

Means followed by the same letter (s) in column and row are not significantly different at 5 $\%$ level as determined by DMRT

\section{CONCLUSIONS}

Biofertilizers increase the efficiency of nitrogen fertilizer (at every dose addition of biofertilizer has increased yield), increase the yield and quality of cauliflower and bring more profit to farmers. Therefore, farmers in resource poor condition can effectively utilize the biofertilizers to get more yield and income with limited use of nitrogenous fertilizer and further research is needed to investigate the long term effect of biofertilizer sustainable soil fertility management and crop production. The results obtained from the investigation indicated that curd yield, curd quality and growth parameters of cauliflower recorded at $120 \mathrm{~kg} \mathrm{~N} \mathrm{ha}^{-1}$ were almost similar to those recorded at $60 \mathrm{~kg} \mathrm{~N} \mathrm{ha}^{-1}$ and $2 \mathrm{~kg}$ biofertilizer ha${ }^{1}$. Biofertilizer did not completely replace nitrogen, but reduced the nitrogen requirement 
to almost half. Resource poor subsistence farmers who are not in a position to afford full dose of chemical fertilizers may apply half dose of nitrogen by inorganic sources and rest half by biofertilizer.

\section{ACKNOWLEDGEMENT}

The author expresses his sincere gratitude to Small Research Grant Award Program of Global Future Institute, USA and Directorate of Research and Publication, IAAS for financial support.

\section{REFERENCES}

Bhattacharyya, P. and B. Shrivastava, 1999. Biofertilizer technology, marketing and uses. Fertilizer Development and Consultation Organization, New Delhi, India.

Bhattacharya, P., R. K. Jain and M. K. Paliwal, 2000. Biofertilizers for vegetables. Indian Journal of Horticulture, 40(2):12-13.

Bhattarai, D. R. and K. Budhathoki, 2005. Effect of organic manures on post harvest physiology and consumer's acceptability of cauliflower. Nepal Journal of Science and Technology, 6:11-14. Nepal Academy for Science and Technology, Lalitpur, Nepal..

Bhattarai, S., S. K. Bajracharya and S. K. KC, 2005. Isolation, identification and production of bacterial fertilizer for legume and non legumes. Annual report, Soil Science Division, Nepal Agriculture Research Council, Khumaltar, Lalitpur, Nepal.

Budhathoki, K. D., R. Bhattarai and N. Joshi, 2006. Effect of biopesticides on reducing the important diseases for organic vegetable production. In: G. Sharma and P. Thapa (eds.). Proceedings of National Workshop on Organic Agriculture and Food Security. Nepal Permaculture Group. Kathmandu. pp. $59-63$

Choudhury, B., 1977. Vegetables. National Book Trust. New Delhi, India.

Cosico, W. C., 1994. Are microbial inoculants necessary for composting? The Philippine Agriculturist, 77(1):67-76.

Fulchieri, M., C. Lucangeli and R. Bottini, 1993. Inoculation with Azospirillum lipoferum affects growth and gibberellins status of corn seedling roots. Plant and Cell Physiology, 34(8):1305-1309.

Gupta, A. K. and R. K. Samnotra, 2004. Effect of biofertilizers and nitrogen on growth, quality and yield of cabbage cv Golden Acre. Environment and Ecology, 22(3):551-553. MKK publication, India..

Kalyani, D. P., C. Ravi Sankar, R. N. Pillai and D. Manohar Prasad, 1992. Studies on the effect of itrogen and Azospirillum on dry matter and nutrient uptake of cauliflower. Vegetable Science, 9(2): 147-151.

Motsara, M. R., P. Bhattacharyya and B. Shrivastava, 1999. Biofertilizer technology, marketing and uses. Fertilizer Development and Consultation Organization, India.

Subbaiah, K., 1994. Studies on the effect of nitrogen and Azospirillum on okra. South Indian Horticulture, 39:37-44. 


\section{ANNEXES}

Table.1: An analysis report of soil samples from three blocks of experimental plot before field experiment at Rampur during 2007 - 2008.

\begin{tabular}{lllll}
\hline Details/Block & I & II & III & Mean \\
\hline $\mathrm{pH}$ & 5.23 & 5.19 & 5.09 & 5.17 (Acidic) \\
Organic Matter (\%) & 2.6 & 2.3 & 2.5 & 2.46 (Low) \\
Available Nitrogen (\%) & 0.121 & 0.112 & 0.114 & 0.115 (Medium) \\
Available Phosphorus $\left(\mathrm{kg} \mathrm{ha}^{-1}\right)$ & 44.2 & 32.1 & 26.2 & 34.16 (Medium) \\
Available Potassium $\left(\mathrm{kg} \mathrm{ha}^{-1}\right)$ & 130.6 & 145.7 & 156.2 & 144.16 (Medium) \\
Soil Texture & S. loam & S. loam & S. loam & Sandy loam \\
\hline
\end{tabular}

Source: Soil science laboratory, NARC, Khumaltar, Lalitpur, Nepal 